\title{
INTERNATIONAL CRIMINAL COURTS AND TRIBUNALS
}

\section{The actus reus of the crime of aggression}

\author{
Nikola R. Hajdin* \\ Department of Law, Stockholm University, Universitetsvägen 10 C, 10691 Stockholm, Sweden \\ Email: nikola.hajdin@juridicum.su.se
}

\begin{abstract}
To adjudicate a claim on individual criminal responsibility, the court has to establish objective and subjective links between the individual and the crime. This article studies the material (actus reus/objective) elements of the crime of aggression (conduct, consequence and circumstance) and suggests a reading that solves most of the conceptual and practical issues regarding criminal responsibility for this crime. The main contribution is an ontological distinction between the material act of use of violence and the act of aggression, which are both subsumed under the term 'state/collective act'. The former is a consequence element and therefore is to be understood in its naturalistic meaning - a perceivable result of one's action. The latter is a legal-evaluative notion and as such constitutes a circumstance that renders the violation of the prohibitory norm (the union of conduct and consequence) as being wrongful. This distinction is crucial for the system of attribution of criminal responsibility, as different mental (subjective) elements apply to consequences and circumstances.
\end{abstract}

Keywords: actus reus; crime of aggression; ICC; material elements; Rome Statute

\section{Introduction}

Aggression is a particularly grave and manifestly illegal use of force by a state. The crime of aggression criminalizes individuals for their contributions to state aggression. ${ }^{1}$ Since 17 July 2018, the crime is fully operational at the International Criminal Court (ICC). ${ }^{2}$ Much has been written about the crime and its future prospects. However, the question of who is to be held accountable for aggression remains puzzling. There is clear consensus among international lawyers that only leaders ought to be blamed for aggression. ${ }^{3}$ This proposition dates back to the post-Second World War trials, where the prevailing opinion was that only the policy

*This article was written during my fellowship at the Institute for Global Law and Policy at Harvard Law School. The time I spent in the US enabled me to discuss my theory with some of the most prominent international law figures of our time, and for that I am indebted to David Kennedy. For potent contributions and insightful comments on the text, I am grateful to Thomas Weigend, Roger Clark, Christoffer Wong, Beth van Schaack, Pål Wrange, Elies van Sliedregt, Dustin A. Lewis, George P. Fletcher, Tom Dannenbaum, and participants in the workshop organized by the Harvard Law School Program on International Law and Armed Conflict. As for mistakes, the buck stops with me.

${ }^{1}$ Traditionally, the norms on aggression in international law have been understood to bind states only. See C. Kre $\beta$, 'The State Conduct Element', in C. Kreß and S. Barriga (eds.), The Crime of Aggression: A Commentary (2017), 412, at 412.

${ }^{2}$ ICC-ASP/16/ Res.5.

${ }^{3}$ Virtually every commentator tackling the issue of criminal responsibility for the crime of aggression has accepted the notion of leadership responsibility. See, e.g., D. Akande and A. Tzanakopoulos, 'The Crime of Aggression before the International Criminal Court: Introduction to the Symposium', (2018) 29 European Journal of International Law 829, at 829. The authors take it as an axiom that only leaders may be prosecuted for aggression.

(C) The Author(s), 2021. Published by Cambridge University Press. This is an Open Access article, distributed under the terms of the Creative Commons Attribution licence (http://creativecommons.org/licenses/by/4.0/), which permits unrestricted re-use, distribution, and reproduction in any medium, provided the original work is properly cited. 
makers could be responsible for the crime. ${ }^{4}$ Since then, it has been generally accepted that only high-ranking state agents can be held responsible for the crime of aggression, whereas common foot soldiers and followers ought to be excluded from criminal responsibility. ${ }^{5}$ To this end, Article $8 b i s$ of the Statute of the International Criminal Court (Rome Statute) ${ }^{6}$ defines the crime of aggression as follows:

For the purpose of this Statute, "crime of aggression" means the planning, preparation, initiation or execution, by a person in a position effectively to exercise control over or to direct the political or military action of a State, of an act of aggression which, by its character, gravity and scale, constitutes a manifest violation of the Charter of the United Nations.

This so-called 'leadership clause' ('a position effectively to exercise control over or to direct the political or military action') is also referred to in Article 25 of the Rome Statute, which stipulates that the Article's provision on modes of criminal responsibility applies only to a person who meets the requirements of this clause. ${ }^{7}$ Given that there is no analogous jurisprudence to guide the interpretation of the clause, ${ }^{8}$ what constitutes leadership in this context is a question that the ICC will have to deal with.

The essence of individual criminal responsibility is the appraisal of individual contribution against the requirements imposed by the basic structure of international crimes. ${ }^{9}$ Pursuant to the Rome Statute, international crimes consist of material (actus reus/objective) and mental (mens rea/subjective) elements. In order to establish guilt, the court has to make objective and subjective links between the accused and the offence in question. ${ }^{10}$ The objective aspect is further broken down into conduct, consequence and circumstance, while the subjective aspect consists of intent and knowledge. Whilst mental elements are quite straightforward, ${ }^{11}$ what constitutes conduct, consequence and circumstance is not as obvious. It is the collective act that bedevil[s] the crime of aggression ... [and] complicates individual criminal responsibility'. ${ }^{12}$ In particular, there is confusion about whether the collective act (intrinsic to the crime) is a consequence or a circumstance element.

The distinction between material elements is crucial for at least three reasons. First, different mental elements apply to conduct, consequence and circumstance. Second, as a rule, individuals are blamed for the caused wrong that is manifested in the consequence element of the crime and not for the surrounding circumstances in which the criminal act took place. Circumstances exist irrespective of the perpetrator's conduct. ${ }^{13}$ Third, the leadership clause requires that a perpetrator 'control or direct' 'state action'. Given the surrounding confusion, state action (collective act) could be interpreted as either a consequence or a circumstance element or both. Therefore, a

\footnotetext{
${ }^{4}$ United States v. von Leeb et al., Military Tribunal XII (hereinafter High Command Judgment), 11 Trials of War Criminals Before the Nuremberg Military Tribunals Under Control Council Law No. 10 (1950), at 488.

${ }^{5}$ See M. Gillett, 'The Anatomy of an International Crime: Aggression at the International Criminal Court', (2013) 3 International Criminal Law Review 829, at 860.

${ }^{6}$ Statute of the International Criminal Court, Art. 5, UN Doc. A/Conf.183/9 (1998).

${ }^{7}$ Art. 25(3bis) Rome Statute.

${ }^{8}$ The leadership standard applicable during the Second World War trials was 'shape or influence'. For a comprehensive account see N. Hajdin, 'The Nature of Leadership in the Crime of Aggression: The ICC's New Concern?', (2017) 17 International Criminal Law Review 543.

${ }^{9}$ See Section 2 below.

${ }^{10}$ See T. Weigend, 'Problems of Attribution in International Criminal Law: A German Perspective', (2014) 12 Journal of International Criminal Justice (2014) 253, at 254.

${ }^{11}$ Intent and knowledge refer to material elements. See Art. 30 Rome Statute.

${ }^{12}$ T. Dannenbaum, 'Aggression and Atrocity: The Interstate Element, Politics, and Individual Responsibility', in E. Conze and S. Bock (eds.), Rethinking the Crime of Aggression: International and Interdisciplinary Perspectives (forthcoming), available at papers.ssrn.com/sol3/papers.cfm?abstract_id=3383214, at 6 .

${ }^{13}$ See Section 3.2 below.
} 
proper understanding of the actus reus of the crime of aggression would help situate the leadership clause within the objective-subjective paradigm, assist in its correct interpretation, and ultimately answer the questions of who is to be blamed and for what.

In this article I suggest a reading of the actus reus of the crime of aggression, focusing primarily on understanding conduct and distinguishing between consequence and circumstance. The main contribution the article makes is the distinction between the material act of use of violence and the normative term 'act of aggression', both of which are subsumed under 'state/collective act'. The discussion concerning the leadership requirement (a circumstance element) is left for a follow-up to this piece. The remainder of this article is structured as follows. Section 2 briefly lays out the objective and subjective elements that underpin international crimes. To establish one's criminal responsibility, the court must perform an assessment against the backdrop of the basic structure of international crimes. In other words, the court has to draw objective and subjective links between the accused and the crime. Subsequently, the article analyses the actus reus trichotomy of the crime of aggression. Section 3.1 suggests a reading of conduct not as planning, preparation, initiation, and execution but rather as a contribution to one of these stages. Section 3.2 makes a distinction between the material act of use of violence and the normative term 'act of aggression', whereby the former is the consequence and the latter the circumstance element. Section 4 summarizes the main findings of the article.

\section{The basic structure of international crimes}

The structure of international core crimes can be conceptualized along two axes. Leaving a broader theoretical discussion aside, ${ }^{14}$ it is now well-accepted in international criminal law that international crimes consist of material and mental elements. ${ }^{15}$ The former is further broken down into conduct, consequence, and circumstance, while the latter presupposes a required state of mind (intent and knowledge), viz. the psychological relationship between the offender and the offence. ${ }^{16}$ This approach emanates from the common law tradition and was adopted at the tribunals for the former Yugoslavia and Rwanda. Article 30 of the Rome Statute prescribes the necessary mental elements and is seen as a general provision in international criminal law. ${ }^{17}$ As a rule,${ }^{18}$ in order to be blamed for the crime in question, the person has to voluntarily engage in the conduct, be aware of all required circumstances prescribed by the specific crime, and be virtually certain that the consequence will occur. ${ }^{19}$ The Rome Statute does not have an analogous provision on material elements; rather, they are listed in the definitions of the crimes (Articles. 6-8bis) ${ }^{20}$ Moreover, the Elements of Crimes focus on the material elements that are associated with each core crime. ${ }^{21}$

The mental and material elements of crimes constitute what might be referred to as the basic structure of international crimes. ${ }^{22}$ There is no criminal responsibility if the accused's involvement is not appraised against this backdrop. In other words, a person is to be found guilty only if she has an objective and subjective relationship with the crime. The following section studies conduct, consequence and circumstance for the crime of aggression. The accompanying mental elements

\footnotetext{
${ }^{14} \mathrm{~K}$. Ambos, Treatise on International Criminal Law, Volume I: Foundations and General Part (2013), at 99-100. Ambos states that case law suggests a twofold structure of international crimes based on the common law dichotomy between offence and defence and, at the level of the former, between material and mental elements.

${ }^{15}$ See G. P. Fletcher, The Grammar of Criminal Law: American, Comparative, and International (2007), at 46.

${ }^{16}$ See A. Cassese, International Criminal Law (2013), at 38-9.

${ }^{17}$ Ambos, supra note 14 , at 266.

${ }^{18}$ Art. 30 starts with 'Unless otherwise provided', which means that it applies to all situations where the crime in question does not require a different mental element(s). See Art. 30(1) Rome Statute.

${ }^{19}$ Emphasis added.

${ }^{20}$ See W. Schabas, The International Criminal Court: A Commentary on the Rome Statute (2016), at 630.

${ }^{21}$ See ICC Elements of Crimes, General introduction, para. 7.

${ }^{22}$ The term 'basic structure of international crimes' is the author's syntactical choice.
} 
will only be briefly mentioned, as they can easily be understood by a plain reading of Article 30 of the Rome Statute. ${ }^{23}$

\section{Material elements}

Material elements determine whether the individual acted wrongfully, and wrongfulness is nothing other than a breach of a prohibitory norm ${ }^{24}$ - a norm that prohibits the criminal conduct. It was only in the later stage of the drafting process prior to Kampala Review Conference 2010 that the Special Working Group for the Crime of Aggression (SWGCA) shifted its focus from a 'complex discussion on entry-intoforce procedures ${ }^{25}$ to writing amendments to the Elements of Crimes with regard to the crime of aggression. In April 2009, 23 experts were invited to an informal meeting held in Montreux, Switzerland, to discuss in their personal capacity future elements of the crime. This meeting was inspired by the draft proposal prepared by Australia and Samoa. ${ }^{26}$ The SWGCA Chair subsequently based his 2009 Chairman's Non-paper on the Elements of Crimes on the conclusions reached in Montreux. ${ }^{27}$ The final version of the Elements of Crimes was adopted in Kampala 2010 and reads as follows:

\section{Article 8 bis}

\section{Crime of aggression}

\section{Introduction}

1. It is understood that any of the acts referred to in article 8 bis, paragraph 2 , qualify as an act of aggression.

2. There is no requirement to prove that the perpetrator has made a legal evaluation as to whether the use of armed force was inconsistent with the Charter of the United Nations.

3. The term "manifest" is an objective qualification.

4. There is no requirement to prove that the perpetrator has made a legal evaluation as to the "manifest" nature of the violation of the Charter of the United Nations.

\section{Elements}

1. The perpetrator planned, prepared, initiated or executed an act of aggression.

2. The perpetrator was a person in a position effectively to exercise control over or to direct the political or military action of the State which committed the act of aggression.

3. The act of aggression - the use of armed force by a State against the sovereignty, territorial integrity or political independence of another State, or in any other manner inconsistent with the Charter of the United Nations - was committed.

4. The perpetrator was aware of the factual circumstances that established that such a use of armed force was inconsistent with the Charter of the United Nations.

5. The act of aggression, by its character, gravity and scale, constituted a manifest violation of the Charter of the United Nations.

6. The perpetrator was aware of the factual circumstances that established such a manifest violation of the Charter of the United Nations.

\footnotetext{
${ }^{23}$ For a good account of the mental elements of the crime of aggression see N. Weisbord, 'The Mens Rea of the Crime of Aggression', (2013) 12 Washington University Global Studies Law Review 487.

${ }^{24}$ 'The standard cases of criminal liability are those in which an individual violates a prohibitory norm'. See G. P. Fletcher, Rethinking Criminal Law (2000), at 581.

${ }^{25}$ See S. Barriga, 'Negotiating the Amendments on the Crime of Aggression', in C. Kreß and S. Barriga (eds.), The Travaux Préparatoires of the Crime of Aggression (2012), 3, at 36-41.

${ }^{26}$ F. Anggadi, G. French and J. Potter, 'Negotiating the Elements of the Crime of Aggression', in ibid., 58, at 63.

${ }^{27} 2009$ Chairman's Non-Paper on the Elements of Crimes', reprinted in ibid., at 677.
} 
What follows is a discussion regarding the three constitutive material elements, namely, conduct, consequence and circumstance. Paragraphs 1 to 6 under sub-heading 'Elements' will henceforth be referred to as Elements 1 to 6.

\subsection{Conduct}

In its literal translation, actus reus means 'guilty act'. However, stricto senso, it is the conduct that denotes an action or omission that is contained in the definition of a specific crime. ${ }^{28}$ An action always renders a change in the material world (e.g., firing of a pistol). Conversely, an omission is non-performance of an action in instances where there is a legal duty to perform. In the criminal law context, actions are exclusively human products. ${ }^{29}$ In other words, they are always attributable to a human person. Consider, as an example, drone strikes. In the pursuit of a legitimate military aim, a highly sophisticated unmanned aircraft autonomously performs what could be considered the conduct element of actus reus (e.g., bombing of a village and killing civilians in the midst of armed conflict). Yet, it is not the object (drone in this case) that will incur criminal lability but a human being to whom this action ought to be imputed. The drone is merely a means to an end.

Element 1 and Article 8bis of the Rome Statute define the conduct of the crime of aggression as planning, preparation, initiation or execution of an act of aggression. The conduct verbs are very similar to the respective provisions in the charters of international military tribunals in Nuremberg and Tokyo, which referred to 'planning, preparation, initiation or waging' of an aggressive war. ${ }^{30}$ The replacement of 'waging' with 'execution' follows linguistic coherence given that the term 'war of aggression' was replaced by 'act of aggression'. ${ }^{31}$ The term 'act' is temporally more determined than the term 'war' in that the latter entails a lapse of time in which the former occurs. It follows that one does not wage an act of aggression but rather executes it. ${ }^{32}$

Defining conduct as planning, preparation, initiation or execution came as a result of the adoption of the so-called 'differentiated' approach during the negotiations prior to Kampala 2010. By the same token, the competing 'monistic' approach ${ }^{33}$ - originally propounded in July $2002^{34}$ suggested the exclusion of the application of different modes of criminal responsibility contained in Article 25 of the Rome Statute. ${ }^{35}$ Accordingly, the conduct element of the crime of aggression was defined in the 2002 paper as follows (see italics):

For the purpose of the present Statute, a person commits a "crime of aggression" when, being in a position effectively to exercise control over or to direct the political or military action of a State, that person intentionally and knowingly orders or participates actively in the planning, preparation, initiation or execution of an act of aggression which, by its character, gravity and scale, constitutes a flagrant violation of the Charter of the United Nations. ${ }^{36}$

\footnotetext{
${ }^{28} \mathrm{Cf}$. section 1.13 of the Model Penal Code (MPC): 'conduct' is 'an action or omission and its accompanying state of mind, or, where relevant, a series of acts and omissions'; for example, an action could be 'planning' of the crime of aggression; see Art. 8bis(1) Rome Statute; an example of omission is 'starvation of civilians as a method of warfare' in armed conflict, Art. 8(2)(b)(xxv) Rome Statute.

${ }^{29}$ The MPC considers in Section 1.13 'act' or 'action' exclusively as a bodily movement.

${ }^{30}$ See Art. 6(a) of the London Charter and Art. 5(a) of the Statute of the International Military Tribunal for the Far East.

${ }^{31}$ See E. Freiburg and A. Zimmermann, 'Article 8bis. Crime of Aggression', in K. Ambos and O. Triffterer (eds.), The Rome Statute of the International Criminal Court (2016), 580, at 587.

${ }^{32}$ On this point see C. McDougall, The Crime of Aggression under the Rome Statute of the International Criminal Court (2013), at 188-9.

${ }^{33}$ Both 'monistic' and 'differentiated' labels were adopted during the sessions exclusively for the sake of convenience, mainly because the former does not differentiate between the commission of the crime (principal responsibility) and complicity (accessorial responsibility), whereas the latter does. See '2005 Discussion Paper 1', reprinted in Kre $\beta$ and Barriga, supra note 25, 471, at 472 (hereinafter Discussion Paper 1).

${ }^{34}$ See '2002 Coordinator's Paper (July)', reprinted in Kre $\beta$ and Barriga, ibid., at 412.

${ }^{35}$ Ibid., at 412 , para. 3 .

${ }^{36}$ Ibid., at 412 .
} 
This approach was labelled monistic, as it does not differentiate between the commission of the crime (principal responsibility) and other forms of participation (complicity). ${ }^{37}$ Consequently, the terms 'orders' and 'participates' exhaustively define the conduct. ${ }^{38}$ Conversely, the differentiated approach suggested the application of the entire Article 25 of the Rome Statute to the crime of aggression with all forms of responsibility therein. ${ }^{39}$ This approach contained three elements: the applicability of the entire Article 25, the addition of the leadership clause thereto, and the description of the conduct element. ${ }^{40}$ Furthermore, it was decided that the chapeau of the crime has to contain the conduct verb(s) in order to describe what the perpetrator's commission actually means, which ultimately is not an easy task. ${ }^{41}$ Nonetheless, in 2007, consensus on the differentiated approach was finally reached, setting on the conduct verbs such as 'planning, preparation, initiation or execution'. ${ }^{42}$

What is clear outright from the disjunctive 'or' is that conviction is secured if the prosecution proves that the accused performed only one action caught by the conduct verbs. As to the exact meaning of each of the conduct verbs, there seems to be a consensus in scholarship that the Nuremberg and Tokyo precedents are not very helpful in deciphering the terms. ${ }^{43}$ McDougall appraised a large chunk of post-Second World War case law $^{44}$ and went further to say that it is impossible to draw firm conclusions in relation to the definition of the terms "planning", "preparing" or "initiating", given the lack of consideration given to these terms'. ${ }^{45}$ Her conclusion is that the courts sought to stress the significance of individual contribution rather than expounding on the conduct verbs. Roger Clark similarly thinks that the courts in the aftermath of the Second World War were not particularly helpful in defining the terms. ${ }^{46}$ Yet, there is some guidance to be found in legal sources that, when coupled with the literal meaning of the terms, could bring us closer to understanding.

\footnotetext{
${ }^{37}$ See Discussion Paper 1, at 472.

${ }^{38}$ Ibid.

${ }^{39}$ Ibid.

${ }^{40}$ Ibid., at 473 .

${ }^{41}$ The negotiation process stumbled over the issue of conduct verbs at some point. Delegations suggested different verbs, and it was not clear which of the approaches would ultimately prevail. Roger Clark, who was present at the time, noted: ' $[t]$ he search for an appropriate conduct word continued over the next couple of years. Both the monist approach and the differentiated approach had their adherents, but the differentiated one was slowly winning. Various new verbs, such as "organize" and "lead" ("what leaders do"), were mooted and found wanting'. R. Clark, 'Individual Conduct', in C. Kre $\beta$ and S. Barriga (eds.), The Crime of Aggression: A Commentary (2017), 565, at 580.

${ }^{42}$ The SWGCA report from December 2007 reads: '[t]he [Chairman's] non-paper met with broad agreement among delegations, and no suggestions for improving its first paragraph were made. It was emphasized that the first paragraph of the non-paper duly reflected the leadership nature of the crime. Delegations commended the fact that the same structure was used as for other crimes under the Statute. Furthermore, by using the phrase "planning, preparation, initiation or execution", the text closely mirrored the language used at Nuremberg. The use of this phrase also avoided the difficult choice of a conduct verb to link the conduct of the individual to the act of State, and was considered altogether an elegant solution'. '2007 SWGCA Report (December)', reprinted in Kre $\beta$ and Barriga, supra note 25, 584, at 585.

${ }^{43}$ E.g., R. Cryer et al. state that ' $[i] t$ is difficult to distinguish planning from perpetration in jurisprudence'. R. Cryer et al., $A n$ Introduction to International Criminal Law and Procedure (2014), at 314; Roger Clark thinks that the analysis of the Nuremberg judgment is not helpful at all in this respect, see R. S. Clark, 'Nuremberg and the Crime against Peace', (2007) 6 Washington University Global Studies Law Review 527; McDougall suggests that '[w]hile the IMT identified the positive acts of each accused that advanced the Nazi's aggressive plans for war, it provided little indication of whether such conduct should properly be defined as "planning", "preparing”, “initiating” or "waging” wars of aggression', C. McDougall, 'The Crimes against Peace Precedent', in C. Kre $\beta$ and S. Barriga (eds), The Crime of Aggression: A Commentary (2017), 49, at 85.

${ }^{44} \mathrm{McD}$ ougall, ibid.

${ }^{45}$ Ibid., at 100 .

${ }^{46}$ See Clark, supra note 41 , at 567.
} 


\subsection{1 'Planning, preparation, initiation or execution' as conduct verbs}

The literal definition of planning is 'to arrange in advance (an action or proposed proceeding)', 'to devise, contrive, or formulate (a project or manner of proceeding)', 'to lay out in a plan'. ${ }^{47}$ Accordingly, one's participation in devising a plan is what is criminalized. The term 'plan' is defined as '[a]n organized (and usually detailed) proposal according to which something is to be done'. ${ }^{48}$ Freiburg and Zimmermann argue that this means that the perpetrator has to be physically present and give his input during the crucial meetings where the plan for the specific act of aggression is devised. ${ }^{49}$ The criminalization reaches as far as the development of specified plans and operations towards the commission of the particular state action in question. ${ }^{50}$

Preparation has a similar meaning as planning. Looking at the Nuremberg judgment, the ILC held that:

[t]he terms "planning" and "preparation" of a war of aggression were considered by the Tribunal as comprising all the stages in the bringing about of a war of aggression from the planning to the actual initiation of the war. In view of that, the [International Military] Tribunal did not make any clear distinction between planning and preparation. As stated in the judgment, "planning and preparation are essential to the making of war". ${ }^{51}$

According to the Oxford English Dictionary, preparation means ' $t$ the action of preparing something', ' $t$ ] hings done to get ready for an event or undertaking'. ${ }^{2}$ Hence, if planning denotes participation in devising a proposal for action, preparation refers to subsequent and sometimes simultaneous acts of creating conditions that enable such action, for example, creating a public option of the necessity of war through the mainstream media, acquiring weapons, recruiting troops and getting them ready for warfare, and so on. ${ }^{53}$

Initiation denotes the commencement of the use of force required by the definition of the crime of aggression. ${ }^{54}$ The Oxford English Dictionary describes initiation as the act of beginning or starting something. ${ }^{55}$ At the Nuremberg Military Tribunal, initiation was described as ' . . a unilateral operation. When war is formally declared or the first shot is fired the initiation of the war has ended and from then on there is a waging of war between the two adversaries' ${ }^{56}$ The term captures actions on the strategic level pertaining to decisions directly leading to the use of force, as opposed to decisions to act aggressively (planning stage) and decisions at the tactical level that are subsequent to initiation of the state action. ${ }^{57}$

As execution replaced Nuremberg's 'waging', there is no case law or any clarification from the SWGCA regarding this element. According to the dictionary, the term 'execution' denotes 'the action of carrying into effect (a plan, design, purpose, command, decree, task, etc.)' ${ }^{58}$ This stage is subsequent to initiation and therefore encompasses all further actions in furtherance of aggression. Given the leadership nature of the crime, execution is confined to contributions of

\footnotetext{
${ }^{47}$ plan, v.', Oxford English Dictionary (2012), 547.

48' plan, n.', ibid.

${ }^{49}$ See Freiburg and Zimmermann, supra note 31 , at 589.

${ }^{50} \mathrm{Ibid}$.

${ }^{51}$ ILC, 'Principles of International Law Recognized in the Charter of the Nuremberg Tribunal and in the Judgment of the Tribunal', (1950) II Yb ILC at 374, para. 116.

${ }^{52}$ 'preparation', n., supra note 47 , at 567.

${ }^{53}$ See also McDougall, supra note 32 , at 187.

${ }^{54}$ See Freiburg and Zimmermann, supra note 31, at 590.

${ }^{55}$ 'The action of beginning, entering upon, or "starting" something; the fact of being begun; beginning, commencement, origination.' See 'initiation', n., supra note 47 , at 374 .

${ }^{56}$ High Command Judgment, at 485.

${ }^{57}$ Here the leadership requirement precludes responsibility of those who make decisions on a 'micro-strategic' or tactical/ operational level. See McDougall, supra note 32, at 188.

${ }^{58}$ 'execution', n., supra note 47 , at 247.
} 
individuals of greater importance. This argument is in line with the basic premise of the leadership requirement: the crime of aggression is a leadership crime that excludes followers from criminal responsibility. A scenario in which a leader presses a button as a final stage prior to dropping bombs from an aircraft is also conceivable.

\subsection{2 'Planning, preparation, initiation or execution' as stages prior to aggression}

The conduct element is constituted by the integrated conduct verbs: 'planning an act of aggression', 'preparing an act of aggression', 'initiating an act of aggression', and 'executing an act of aggression'. Unlike the other core crimes, the consequence is the same for all of the conduct verbs. $^{59}$ Therefore, another way to look at planning, preparation, initiation or execution is through a prism of stages prior to collective action. Following the linguistic account above, the verbs denote chronological steps that follow one another in bringing about the collective act. This is readily understandable from a plain reading of the terms. To this end, it is true that in order for a synchronized collective action to occur, a proposal of some kind must first be made. Preparations for the execution of such a plan have to follow logically. As a third step, strategic decisions have to be made to narrow down the object that will be absorbed by the action. Finally, in a collective endeavour, someone has to order the beginning of the course of action. The ultimate product or the result of such a collective endeavour is a change in the natural world - in this case the use of violence. ${ }^{60}$ From a legal perspective, these are the stages seen as crucial prior to occurrence of the criminal result since it suffices that an accused is involved in only one of them.

In light of the foregoing, conduct is better read as being a contribution to one of the stages prior to the consequence of the crime. This is true for the other core crimes as well. ${ }^{61}$ The difference between the crime of aggression and the other three core crimes (genocide, crimes against humanity and war crimes) is that the latter do not explicitly contain in their definitions the stages prior to the criminal activity. Whenever there is an element of collectiveness implied in the commission of a certain act, there are at least two stages prior to action, viz. planning and execution of an act. Of course, a soldier may murder or rape someone during an armed conflict on a whim and thus commit a war crime. However, there is no element of collectiveness in such a case, and therefore the only stage of criminal activity is execution.

According to the current doctrine at the ICC, the person in control over the commission of the crime is responsible for the offence as the perpetrator. 'Control' can be exerted not only by those who:

physically carry out the objective elements of the offence but also ... [by] those who, in spite of being removed from the scene of the crime ... mastermind its commission because they decide whether and how the offence will be committed. ${ }^{62}$

ICC Pre-Trial Chamber I defined the 'control' required for perpetration as an essential contribution to the commission of the crime. ${ }^{63}$ By the same token, complicity at the ICC requires a significant contribution to a group's effort as a requirement for individual criminal responsibility. ${ }^{64}$

\footnotetext{
${ }^{59}$ See the following section.

${ }^{60}$ Section 3.2.2 below develops this argument by suggesting that the consequence element of the crime of aggression is the material act of use of violence.

${ }^{61}$ Furthermore, this is true for any crime that is collective in nature.

${ }^{62}$ Prosecutor v. Thomas Lubanga Dyilo, Decision on the Confirmation of Charges, ICC-01/04-01/06, Pre-Trial Chamber I, 29 January 2007, para. 330

${ }^{63}$ Ibid., para. 332(iii).

${ }^{64}$ See M. Cupido, 'Group Acting with a Common Purpose', in J. De Hemptinne et al. (eds.), Modes of Liability in International Criminal Law (2019), 309, at 319.
} 
To sum up, as a rule, contribution to the consequence of the crime is what is required by conduct under the Rome Statute. Given the collective nature of the core crimes, multiple individuals could be criminally responsible without physically bringing about the specific consequence. It is the level of contribution that determines whether the individual caused the consequences. For the crime of aggression, conduct is a contribution of a certain degree (that still remains to be determined) to one of the stages prior to the collective action.

\subsection{Consequence and circumstance}

Actions and omissions are criminally relevant only if they violate the prohibitory norm of the criminal code. Whether conduct is in violation of the law is decided by looking at the particularly relevant occurrence in space and time, which we refer to as the consequence element. ${ }^{65}$ Consequences are thus effects or changes in the material world caused by the offender's action. ${ }^{66}$ Take murder for example. Shooting a pistol may be justified on many occasions. If, however, the actor intentionally causes someone's death, she would regularly be charged with murder. The 'naked' act (firing of a pistol) would be considered the criminal conduct only if the court determines that it caused the relevant change in the material world (death). ${ }^{67}$ In this vein, the consequence requirement qualifies the conduct as being in violation of the prohibitory norm of the criminal code.

Attributing the condition of being in violation of the prohibitory norm (the union of conduct and consequence) to the actor is inconclusive in terms of making an argument on wrongfulness. In addition, there has to be a specific state of affairs, which we call the circumstance element. Circumstances are a factual or legal state of affairs that qualifies the violation of the prohibitory norm as being wrongful. ${ }^{68}$ Furthermore, the circumstance element classifies the violation as a specific crime. For example, an instance of causing (conduct) death (consequence) would normally be charged as murder; if it is committed as part of a widespread or systematic attack against a civilian population, then it could be classified as a crime against humanity. ${ }^{69}$

This is a brief overview of the consequence and circumstance elements. There is much to be said about their nuances, but this short presentation suffices for the present purposes. The crime of aggression criminalizes individuals for their contribution to a collective act of state aggression. During the negotiations prior to Kampala, it was suggested that the act of aggression could be characterized as either the consequence or the circumstance element. ${ }^{70}$ For the sake of convenience, state aggression is thus seen in terms of the latter, without, however, expounding on the consequence element of the crime of aggression. There is both practical and conceptual importance in distinguishing between the two, given that the system of attribution of criminal responsibility requires different subjective and objective links for each. All of this will be shown in the analysis that follows.

\footnotetext{
${ }^{65}$ Roger Clark points out that during the negotiation process preceding the Rome Statute, some of the participants thought about conduct as absorbing results as well. In his example, firing a gun and causing death to a victim is surely conduct. The question is whether the death part is conduct (as its natural extension). See R. S. Clark, 'The Mental Element in ICL: The Rome Statute of the ICC and the Elements of Offences', (2002) 142 Criminal Law Forum 291, at 306 (including accompanying notes 49 and 50).

${ }^{66}$ See Cassese, supra note 16 , at 38.

${ }^{67}$ In cases (such as the present one) where attempt is punishable, the actual death need not occur. Further analysis on attempt will be omitted, as it does not add to the main argument of the article.

${ }^{68}$ Cf. K. J. Heller, 'The Rome Statute of the International Criminal Court', in K. J. Heller and M. Dubber (eds.), The Handbook of Comparative Criminal Law (2010), 593, at 602.

${ }^{69}$ Art. 7 Rome Statute.

${ }^{70}$ See '2009 Montreux Draft Elements of Crimes', reprinted in Kre $\beta$ and Barriga, supra note 25, 669, at 671 (hereinafter 2009 Montreux Draft Elements of Crimes).
} 


\subsubsection{Collective act as a circumstance}

A collective act is an intrinsic part of the crime of aggression, as without it there is no individual criminal responsibility. What do we mean exactly by 'state/collective act' in this context? In order for a person to be prosecuted, an act of aggression has to occur. ${ }^{71}$ In Article 8bis of the Elements of Crimes, Elements 3 and 5 refer to the collective act, whereas Elements 4 and 6 articulate mental elements. Element 3 requires that an act of aggression ('the use of armed force by a State against the sovereignty, territorial integrity or political independence of another State, or in any other manner inconsistent with the Charter of the United Nations') has to be committed, whilst Element 5 requires that the act has to constitute a manifest violation of the UN Charter. Elements 4 and 6 require that the perpetrator was aware of the factual circumstances enabling the inconsistency and manifest violation of the UN Charter. Essentially, Elements 4 and 6 provide the mental requirements for Elements 3 and 5, respectively. This was originally suggested during the informal meeting in Montreux, where Elements 3 and 5 were considered as circumstances. ${ }^{72}$

The Montreux group highlighted the practical issue of characterizing Elements 3 and 5 as consequences, as in such case the required mental element might be difficult to prove. Namely, Article 30 of the Rome Statute stipulates intent and knowledge in relation to consequences in that the perpetrator either means to cause the consequence or is aware that a certain consequence will occur in the ordinary course of events. Crucially, if Elements 3 and 5 were understood in this way, the prosecution must prove that the accused knew that the collective act was both inconsistent with the UN Charter and represented a manifest violation. This may, for instance, allow for the perpetrator to shield his responsibility behind disreputable legal advice. ${ }^{73}$ For these reasons, the Montreux group suggested Elements 4 and 6, which ultimately were adopted in Kampala 2010.

What classifies conduct as being part of the crime of aggression is the existence of an act of aggression that manifestly violates the UN Charter. This is a legal-evaluative concept and as such is to be established by the court. In the Rome Statute, the act of aggression is defined as 'the use of armed force by a State against the sovereignty, territorial integrity or political independence of another State, or in any other manner inconsistent with the Charter of the United Nations' ${ }^{74}$ In other words, not all instances of the use of armed force amount to an act of aggression. ${ }^{75}$ Actually, not even every instance of illegal use of force amounts to aggression. ${ }^{76}$ During the negotiation process preceding the Kampala conference, the SWGCA adopted the 'Understandings', in which points 6 and 7 address these issues:

6. It is understood that aggression is the most serious and dangerous form of the illegal use of force; and that a determination whether an act of aggression has been committed requires consideration of all the circumstances of each particular case, including the gravity of the acts concerned and their consequences, in accordance with the Charter of the United Nations.

7. It is understood that in establishing whether an act of aggression constitutes a manifest violation of the Charter of the United Nations, the three components of character, gravity and scale must be sufficient to justify a "manifest" determination. No one component can be significant enough to satisfy the manifest standard by itself. ${ }^{77}$

\footnotetext{
${ }^{71}$ See Art. 8bis ICC Elements of Crimes, Element 3.

${ }^{72}$ 'For the purposes of this paper, we have characterised proposed Elements 3 and 5 as circumstances', 2009 Montreux Draft Elements of Crimes, at 671.

${ }^{73} 2009$ Montreux Draft Elements of Crimes, at 671.

${ }^{74}$ Art. 8 bis(2) Rome Statute.

${ }^{75}$ For example, Art. 51 of the UN Charter stipulates the right of self-defence as an exception to the prohibition of the use of force.

${ }^{76}$ See C. Stahn, A Critical Introduction to International Criminal Law (2019), at 101.

${ }^{77}$ Understandings regarding the amendments to the Rome Statute of the International Criminal Court on the Crime of Aggression, Ann. II to Res. ICC-RC/Res.6.
} 
This change was motivated by the US delegation, who originally wanted to exclude unilateral humanitarian intervention from the definition of aggression. ${ }^{78}$

To sum up, the circumstance that qualifies the individual conduct as wrongful is the existence of an act of aggression that manifestly violates the UN Charter. This is a normative concept and cannot be deduced solely from the facts perceivable by an ordinary human individual but rather requires a legal evaluation. This decision of whether a particular situation constitutes the circumstances of the crime of aggression is left entirely to the court of law. ${ }^{79}$

\subsubsection{The consequence element}

This Montreux resolution surely has merit. However, it shies away from defining the consequence element of the crime and therefore creates confusion for the attribution of criminal responsibility. To wit, in order to connect the accused with state action and thus prosecute her for aggression, there has to be a clear distinction between conduct, consequence and circumstance. To date, no one has systematically tackled this issue. ${ }^{80}$ The two prominent scholars who engaged with this issue most seriously, Professor Roger Clark and Professor Larry May, do not view it through the prism of attribution of responsibility. Let us first see how they lay out their arguments and then appraise their propositions against the current law.

Looking at the collective act, Roger Clark states the following;

We often think of the state act of aggression as a "(contextual) circumstance" element, as that term is used in article 30 of the Rome Statute and in the drafting of the Elements of Crimes. This is a reasonable way to look at it from the viewpoint of an actor who arrives on the scene at the execution stage and adds to what others have done. But from the point of view of one who is an early planner or preparer, the state act is more of a result element, or even a conduct one. ${ }^{81}$

The following example is illustrative. State A commits aggression against State B. After a few months of the continuous illegal military campaign, State A's high military official P1 steps down for some reason, and P2 takes his place. By virtue of her position, P2 contributes to a strategic decision $^{82}$ and thus initiates the bombardment of State B's capital city by giving specific orders. This was originally contemplated long before P2 assumed the office, and P1 contributed to its planning significantly. In this situation, should such an act of aggression ${ }^{83}$ be characterized as a consequence or circumstance, and is it different in relation to P1 as opposed to P2? In a footnote following his statement, Clark further asserts;

There were different views expressed [during the negotiation process] about whether this [state act] element was a consequence, circumstance or context element. Some commented that aspects of each of these types of element applied to the State act, and it might be more appropriate to take a pragmatic approach and simply specify the required mental element. The issue was not discussed further. A circumstance element normally exists independently of what the accused does. It is part of the background (such as that the goods taken belong to someone else, or that the being who is killed is a human being). For the State act of aggression, somebody needs to create the relevant state of affairs. ${ }^{84}$

\footnotetext{
${ }^{78}$ See McDougall, supra note 32, at 120.

${ }^{79}$ See Barriga, supra note 25 , at $30-1$.

${ }^{80}$ This assertion has been made to the best of my knowledge.

${ }^{81}$ R. S. Clark, 'General Principles of International Criminal Law', in Kre $\beta$ and Barriga, supra note 1, 590, at 617.

${ }^{82}$ Strategic decisions are made in the initiation stage. See Section 3.1.1 above.

${ }^{83}$ For the sake of the argument, the attack on State B's capital city is classified as an act of aggression.
} 
True, circumstances usually exist without the influence of a direct perpetrator ('the one that pulls the trigger'). Criminal conduct is regularly carried out by a person who is not responsible for the context that allowed for the commission of the crime. We normally hold individuals responsible for the consequences of the crime and not for creating the surrounding circumstances. Therefore, Clark is right to say that we ought not to blame someone for creating a state of aggression, as we blame an individual not for creating 'the context of a manifest pattern of similar conduct ${ }^{85}$ in the case of genocide but for the genocide in and of itself. To frame it more technically, we blame genocidaires for the consequence of the crime (murder, rape, etc.) committed with the genocidal intent and not for the context in which the genocide took place.

Be that as it may, in identifying the consequence element for the crime of aggression, a first step ought to be the individualization of the collective act. A single illegal military campaign entails a lapse of time and therefore usually presupposes the occurrence of several acts of aggression. From a criminal law perspective, the perpetrator is responsible for collective acts that result from her contribution. This individualization is warranted given the shift in the definition of the crime from 'aggressive war' to 'act of aggression' as a reference point. Whilst the term 'war' denotes a continuous process ${ }^{86}$ that comprises many acts between the belligerents, the concept of 'act' is more determinate in time. ${ }^{87}$ In the ordinary course of events, one act of aggression is usually followed by many more. However, they are to be understood separately and independently from each other, as they occur sporadically or even coincidentally.

From the perspective of imputation of criminal responsibility, every specific act taken as a reference point ought to be appraised independently. For example, during a continuous military campaign, one military general initiates an illegal armed attack amounting to aggression in village $\mathrm{X}$, whilst another general does the same in village $\mathrm{Y}$. Their criminal responsibility is to be appraised irrespectively of each other based solely on the particular collective act that emerged from their contributions.

This is a coherent reading according to which an individual found in whatever stage prior to the occurrence of the collective act - planning, preparation, initiation or execution - ought to be judged based on the specific collective act resulting from her contribution. Re-reading Clark's argument, the planner is responsible for the collective act she had planned; whoever eventually joins and engages in the illegal military campaign is responsible for the collective act she had contributed to.

In view of the foregoing, the collective act - apart from being a circumstance element - appears to be the consequence element of the crime of aggression. This is, however, an inconclusive statement. In order to comprehend this relationship entirely, a further important distinction must be made between the act of aggression as a legal-evaluative term and the material act of use of violence in its naturalistic sense divorced from any legal evaluation. Let us now examine May's take on the consequence/circumstance dichotomy, as it opens up room for a deeper conceptual discussion.

Professor Larry May asserts that the act of aggression is the circumstance for the crime of aggression. His argument builds on Clark's scholarship ${ }^{88}$ and adds some further nuances. May separates individual and collective conduct by suggesting that an individual cannot engage in an act of aggression since this can be done only by an entity. ${ }^{89}$ According to him, committing an act of aggression is a collective action and as such cannot be reduced to one person's act. As there is no plausible way to look at the collective act as a result of individual conduct, May proposes that:

\footnotetext{
${ }^{84}$ Clark, supra note 81 , at 617 (note 178 ).

${ }^{85}$ See Art. 6(a) ICC Elements of Crimes, Element 4.

${ }^{86}$ Hostile contention by means of armed forces, carried on between nations, states, or rulers, or between parties in the same nation or state'. See 'war', n.1, supra note 47 , at 831.

${ }^{87}$ 'Something done; the action or process of achieving this'. See 'act', n.1., ibid., at 7.

${ }^{88}$ See L. May, Aggression and Crimes against Peace (2008), at 237.

${ }^{89}$ See ibid., at 234 .
} 
[a] more promising approach would be to see State aggression as a circumstance of the acts of the leader who is being prosecuted. This would mean that State aggression is not seen implausibly as what these leaders do but as one of the elements that needs to be proved as a surrounding factor in what the leader did. $^{90}$

Looking at war (May refers to 'war' but actually means 'act of aggression') as a collective endeavour - and by 'collective' he understands 'action of a group, and a group is best understood as individuals in various relationships' - the acts of leaders coupled with the acts of a number of other individuals (he mentions soldiers) bring about its existence. ${ }^{91} \mathrm{He}$ describes the leader's role as 'a very significant' one but not essential by any means. Even in the case of dictatorship, he argues, the collective act cannot be imputed to the leader who declares the war, as there are still many people who are embroiled in facilitating the act of aggression. ${ }^{92}$

Indeed, someone has to recruit military forces, secure public consent, develop strategy, and so on. Essentially, what May proposes is that due to the logical implausibility of connecting individual conduct to the collective act by looking at the latter as a result of the former, the only way is to consider the act of aggression as an 'overarching' element of the crime of aggression. ${ }^{93}$ Consequently, the prosecution must prove that the leader's participation is tied to the circumstances of aggression in that she participated [to a certain degree] in the planning of the collective act.

May's argument is important, as it brings attention to the relationship between the individual acts and the circumstances of the crime. However, it is inconclusive in May's own words ${ }^{94}$ and therefore lacks cohesion when appraised against the backdrop of the basic structure of international crimes. His axiomatic substrate - a claim that collective action cannot be reduced to a single person's conduct - seems incorrect from a criminal law perspective. To wit, criminal law theory through the doctrine of individual criminal responsibility connects the individual contribution to the collective result by looking at the latter as a consequence of the former.

Take the case of persecution as a crime against humanity. ${ }^{95}$ Persecution means 'the intentional and severe deprivation of fundamental rights contrary to international law by reason of the identity of the group or collectivity'. ${ }^{96}$ The crime of persecution targets a group, and the attack has to be widespread or systematic. ${ }^{97}$ 'Attack' is defined as 'a course of conduct involving the multiple commission of acts ... against any civilian population, pursuant to or in furtherance of a state or organizational policy to commit such attack'. ${ }^{98}$ Therefore, persecution is a collective act by a state or organization against a certain civilian population. Like other crimes against humanity, it is often part of a social system of oppression, ${ }^{99}$ and like state aggression, it is performed by multiple individuals.

If one is to espouse May's argument, it would not be possible to connect individual conduct with the collective act of persecution by way of looking at the latter as a result of the former, since May does not accept the possibility of linking the collective act to a single person's conduct. This position must be rejected as it contravenes the system of attribution of individual criminal responsibility in international criminal law.

\footnotetext{
${ }^{90}$ Ibid., at 235.

${ }^{91}$ Ibid.

${ }^{92}$ Ibid., at 236.

${ }^{93}$ See ibid., at $238-9$.

${ }^{94}$ May himself admits that ' $[\mathrm{m}]$ ore good conceptual work needs to be done if this type of international crime is going to be as well defined as the other three types of crime (crimes against humanity, war crimes, and genocide) that the ICC is beginning to prosecute individuals for having committed'. Ibid. at 239.

${ }^{95}$ See Art. 7(1)(h) Rome Statute.

${ }^{96}$ Art. 7(2)(g) Rome Statute.

${ }^{97}$ See Art. 7 Rome Statute.

${ }^{98}$ Art. 7(2)(a) Rome Statute.

${ }^{99}$ See Stahn, supra note 76 , at 57.
} 
The collective act of aggression most certainly cannot be reduced to a single person, not even metaphysically, as May rightfully suggests. However, the doctrine of criminal responsibility connects individuals with the offence by looking at the level of involvement/contribution and the psychological relationship to the crime. In international criminal law, this is done through the prism of the basic structure of international crimes, viz. material and mental elements. While only a state ${ }^{100}$ has the capacity to commit aggression, it is plausible to argue from the perspective of criminal responsibility that an individual contribution (coupled with other individual contributions) may result in a collective act by looking at the former as conduct and the latter as consequence. As Clark said, ' $\mathrm{t}$ ] he act is a "collective" one, but individuals (at least several) are necessary to get it up and running and thus can be responsible for attempting to do so'. ${ }^{101}$ This approach is consistent with the positive law. ${ }^{102}$

3.2.2.1 The material act of use of violence. Accepting a premise that collective action may result from individual conduct by no means suggests that the act of aggression is the consequence element of the crime of aggression. Here I agree with May but for different reasons. While May's argument is borne of the metaphysical implausibility of connecting the individual with the collective, I argue that the act of aggression is the circumstance element for reasons of logical coherence based on plain reading of the law. Namely, Element 1 of the Elements of Crimes for the crime of aggression defines the conduct and reads: 'The perpetrator planned, prepared, initiated or executed an act of aggression.' However, when this provision is read in conjunction with introductory paragraph 2 to Article 8 bis of the Elements of Crimes ('There is no requirement to prove that the perpetrator has made a legal evaluation as to whether the use of armed force was inconsistent with the Charter of the United Nations.'), it leads to the conclusion that the consequence of the crime of aggression can only be the use of armed force. More precisely, the consequence element of the crime of aggression is the material act of use of violence understood solely in its naturalistic sense, perceivable by a human individual at the moment when the conduct took place and divorced from any legal evaluation. The next few paragraphs give reasons for this assertion.

Paragraph 2 of the Introduction to Article 8bis of the Elements of Crimes rules out the possibility that an 'act of aggression' (use of force that is inconsistent with the UN Charter) is a consequence, as there is no need that the perpetrator either intend it or have knowledge that it will occur in the ordinary course of events because there is no need for her to make such a legal evaluation. Another reason why an act of aggression cannot be the consequence element is because it is logically implausible to argue that action may cause normative states. According to the basic structure of international crimes, the perpetrator's conduct causes the consequences of the crime. Consequently, an act of aggression - a legal/normative notion - is not the consequence of the crime but may only be a circumstance element.

\footnotetext{
${ }^{100}$ The Rome Statute definition confines the crime of aggression to inter-state aggression only. There are, however, commentators who advocate for the inclusion of non-state actors. For example, Cassese argues that if the idea of international criminal law is centred around individual criminal responsibility and the purpose of the crime of aggression is to protect the world community from breaches of the peace, then 'one fails to see why individuals operating for non-state entities should be immune from criminal liability for aggressive conduct'. See A. Cassese, 'On Some Problematical Aspects of the Crime of Aggression', (2007) 20 Leiden Journal of International Law 841, at 846; similarly, Mark Drumbl states that there are four interests we aim to protect by criminalizing aggression, namely, stability, security, human rights, and sovereignty. He then argues that the state-centric definition of aggression does not sufficiently protect those interests and therefore should be expanded to include, inter alia, non-state actor violence. See M. A. Drumbl, 'The Push to Criminalize Aggression: Something Lost Amid the Gains', (2009) 41 Case Western Reserve Journal of International Law 291, at 304-11.

${ }^{101}$ Clark, supra note 81 , at 617 .

${ }^{102 ،}$ Crimes against international law are committed by men, not by abstract entities, and only by punishing individuals who commit such crimes can the provisions of international law be enforced.' United States et al. v. Göring et al., Trial of the Major War Criminals before the International Military Tribunal, 14 November 1945-1 October 1946, vol. I (1947), at 447.
} 
It follows that the perpetrator need not have a causal relationship to the existence of aggression. Rather, she has to be mindful of it. Roger Clark explains the relationship between the perpetrator and the circumstance element quite vividly:

It is easy enough to think of "committing" conduct (including conduct by omission), or even of "committing" a consequence, such as a homicide. It is, on the other hand, difficult to think of "committing" a circumstance. It is not my action that makes something the property of another. That is part of the scene (a crucial part) against which I engage in conduct in taking someone else's stuff. I do have an attitude towards it, though, probably "knowledge". Hence, "committed" must be interpreted as meaning something like "accompanied by" in order to make sense in relation to circumstance elements. ${ }^{103}$

Indeed, it is more plausible to argue that the perpetrator was accompanied by an act of aggression rather than committing it. ${ }^{104}$

May correctly looks at the act of aggression as a circumstance element since it is the notion that classifies the perpetrator's conduct as being the crime of aggression. However, as he remains true to his claim that a collective action cannot be narrowed down to a single person's contribution, he does not further distinguish the material act of use of force from the legal notion of act of aggression.

The material act is built in the notion of state aggression. Thus, in order to make a claim on the existence of aggression, we need to observe the particular occurrence in space and time and argue whether or not it constitutes an act of aggression. Therefore, the result or consequence of the individual conduct is the collective action in its naturalistic meaning - a material act caused by the perpetrator's conduct - while the circumstance element that qualifies the individual conduct as being wrongful is the legal/normative concept of 'act of aggression that manifestly violates the UN Charter'.

In international law, the use of force indispensably presupposes violence, as the core of the prohibition of the use of force enshrined in Article 2(4) of the UN Charter and grounded in customary international law ${ }^{105}$ stems from the idea of prohibition of illegal warfare. In his seminal book, War, Aggression and Self-Defence, Professor Yoram Dinstein holds that violence is the essence of warfare. ${ }^{106}$ In his account, he states the following:

Breaking off diplomatic relations with a State, or withdrawing recognition from it, does not suffice. An economic boycott or a psychological pressure is not enough. A "cold war", threats to use force, or even a declaration of war (unaccompanied by acts of violence), do not warrant the conclusion that war in the material sense exists. It is indispensable that violence will occur. ${ }^{107}$

Following this train of thought, the naturalistic manifestation of an act of aggression is the material act of use of violence by a state against another state. ${ }^{108}$

\footnotetext{
${ }^{103}$ Clark, supra note 65, at 307 (note 54). Clark wrote directly to me that he made this remark in the context of explaining that the use of the word 'committed' in Art. 30 of the Rome Statute ('only if the material elements are committed with intent and knowledge') is a poor choice of language when applied to circumstance elements.

${ }^{104}$ Emphasis added.

${ }^{105}$ See ICJ, Case Concerning Military and Paramilitary Activities in and Against Nicaragua (Merits), judgment of 27 June 1986, paras. 172-186.

${ }^{106}$ 'Wartime means the use of armed force, namely, violence.', Y. Dinstein, War, Aggression and Self-Defence (2011), at 9.

${ }^{107}$ Ibid., at 9-10.

${ }^{108}$ Unlike the threat of force, the use of force always presupposes violence. See J. Green and F. Grimal, 'The Threat of Force as an Action in Self-Defense Under International Law', (2011) 44 Vanderbilt Journal of Transnational Law 285, at 311.
} 
In the context of the crime of aggression, violence is a deliberate exercise of force or intimidation by the exhibition of such force by a state against another state. ${ }^{109}$ Depending on the level of intensity, the act of use of violence can be further legally classified as either use of force, an armed conflict or an act of aggression. ${ }^{110}$ Whatever the classification, the naturalistic manifestation is the material act that indispensably presupposes violence and, in the case of the crime of aggression, represents a particularly relevant change in the material world to which we connect the individual conduct when ascribing criminal responsibility.

This is a correct reading of the elements of crimes that solves much of the practical dilemma faced by the Montreux group. According to the required mens rea standard in Article 30 of the Rome Statute, intent of the accused covers the material act of use of violence and not the act of aggression, and therefore there is no need for the prosecution to prove that she made any prior legal evaluation.

\section{Conclusion}

A criminal offence is an action or omission attributable to a human person, performed under a certain state of affairs, that violates a prohibitory norm of the criminal code. In other words, it is conduct performed under circumstances that results in consequences. This trichotomy - conduct, consequence and circumstance - constitutes the actus reus paradigm of the basic structure of international crimes that has to be linked with the accused in order to hold her criminally responsible. The analysis above suggests that individual conduct for the crime of aggression is best understood as a contribution to one of the crucial stages (planning, preparation, initiation or execution) prior to the collective action. In order to satisfy the requirement imposed by the conduct element, it is enough to show that the accused had a certain level of contribution to only one of the stages. The consequence element is the collective act of use of violence. This is to be understood in its naturalistic sense, divorced from any legal evaluation, as the material act of use of violence of a state against another state. What classifies the perpetrator's conduct as wrongful (the circumstance element) is the existence of an act of aggression that manifestly violates the UN Charter. An act of aggression - a legal state of affairs - is a single instance of the use of violence that manifestly violates the UN Charter only if it is characterized as such by a court of law. In other words, the notion of 'act of aggression' is a normative term that is subject to a legal evaluation. Consequently, questions of what is a 'state', what amounts to use of force, what does 'against the sovereignty, territorial integrity or political independence of another state, or in any other manner inconsistent with the Charter of the United Nations' mean, what are examples of other non-listed acts of aggression, and so forth are to be resolved by a court. ${ }^{111}$

\footnotetext{
${ }^{109}$ 'violence', n., supra note 47 , at 825 .

${ }^{110}$ For the examples see, e.g., Art. 8bis(2) Rome Statute.

${ }^{111}$ For a detailed treatment see Kre $\beta$, supra note 1.
}

Cite this article: Hajdin NR (2021). The actus reus of the crime of aggression. Leiden Journal of International Law 34, 489-504. https://doi.org/10.1017/S0922156521000042 